\title{
Wykładnia art. 23 ust. 2 regulaminu Sejmu - odwołanie od uchwały Prezydium Sejmu o obniżeniu uposażenia lub diety parlamentarnej ${ }^{1}$
}

Interpretation of Article 23 para. 2 of the Standing Orders of the Sejm - an appeal against a resolution of the Presidium of the Sejm on decreasing the salary of a Deputy or parliamentary per diem allowance (WAUiP-2305/17): Analysis of the matter of decisions that may be taken by the Presidium of the Sejm, considering an application for reconsideration of the case. In the author's opinion, the scope of possible decisions of the Presidium of the Sejm, made on the basis of the analyzed provision, includes: sustaining the original resolution, repealing it, as well as changing the amount of deprivation of Deputy's benefits made in the original resolution (in favour of the appealing Deputy).

Keywords: Deputy, Presidium of the Sejm, Standing Orders of the Sejm

Słowa kluczowe: poseł, Prezydium Sejmu, regulamin Sejmu

Ekspert ds. legislacji BAS; wojciech.sypniewski@sejm.gov.pl.

\section{Przedmiot opinii}

Przedmiotem opinii jest wykładnia art. 23 ust. 2 regulaminu Sejmu. Wątpliwość, dotyczy tego, czy Prezydium Sejmu, rozpatrując wniosek o ponowne rozpatrzenie sprawy, przedłożony w trybie art. 23 ust. 2 regulaminu Sejmu, może jedynie uchylić lub utrzymać w mocy pierwotną uchwałę, czy też może obniżyć dietę (uposażenie) w wymiarze innym niż ustalony w pierwszej uchwale?

Opinia prawna na temat wykładni art. 23 ust. 2 regulaminu Sejmu (odwołanie od uchwały Prezydium Sejmu o obniżeniu uposażenia lub diety parlamentarnej) sporządzona 17 listopada 2017 r. na zlecenie zastępcy Szefa Kancelarii Sejmu; BAS-WAUiP 2305/17. 


\section{Tryb rozpatrywania spraw posłów uniemożliwiających pracę Sejmu lub jego organów}

1. Odpowiedzialność regulaminowa posłów na podstawie art. 23 ust. 1 dotyczy „uniemożliwiania pracy Sejmu lub jego organów”. Pojęcie to obejmuje klasę czynów (działań lub zaniechań), które prowadzą do dezorganizacji pracy Sejmu lub jego organów. Z pojęciem „uniemożliwiania pracy” mogą wiązać się różne sytuacje faktyczne, które trudno byłoby sprecyzować w przepisach regulaminu Sejmu².

Prezydium Sejmu wykonując kompetencję, o której mowa w art. 23, podejmuje swoje działania z urzędu. Inspiracją dla działań Prezydium Sejmu mogą być informacje przekazane przez Marszałka Sejmu albo przedstawiciela organu, którego prace zostały zakłócone, ale także informacje pochodzące z innych źródeł. Inicjatorem działań Prezydium Sejmu w tych sprawach najczęściej będzie Marszałek Sejmu, ponieważ to na nim ciąży obowiązek sprawowania pieczy nad spokojem i porządkiem na całym obszarze należącym do Sejmu (art. 10 ust. 1 pkt 13 regulaminu Sejmu), a także do niego należy ustalanie porządku dziennego i terminów posiedzenia Prezydium Sejmu (art. 13 ust. 1 regulaminu Sejmu). W praktyce od Marszałka Sejmu zależeć będzie zatem, czy Prezydium Sejmu podejmie działania zmierzające do egzekwowania tej formy odpowiedzialności regulaminowej ${ }^{3}$.

Prezydium Sejmu, rozpatrując sprawy z art. 23 regulaminu Sejmu, korzysta z typowych instrumentów służących wyjaśnieniu badanej sprawy (analiza dokumentów, wysłuchanie wyjaśnień zainteresowanego lub innych osób mających wiedzę na temat sprawy). Prezydium Sejmu nie przysługują jednak w tym zakresie żadne środki o charakterze władczym. Przepisy regulaminu Sejmu nie gwarantują zainteresowanemu posłowi prawa udziału w posiedzeniu Prezydium Sejmu, na którym rozpatrywana jest jego sprawa.

Uchwała Prezydium Sejmu stanowi wynik oceny okoliczności czynu, który spowodował uniemożliwienie pracy Sejmu lub jego organów, i może przewidywać obniżenie uposażenia lub diety parlamentarnej posła, w wysokości nieprzekraczającej 1/2 wysokości uposażenia poselskiego lub pełnej diety parlamentarnej miesięcznie na okres nie dłuższy niż 3 miesiące. Należy podkreślić, że nałożenie przez Prezydium Sejmu sankcji za naruszenie porządku pracy ma charakter fakultatywny. Mimo stwierdzenia deliktu Prezydium Sejmu zachowuje swobodę w zakresie wymierzenia kary (np. może odstąpić od wymierzenia kary finansowej z uwagi na okoliczności zdarzenia). Uchwała o obniżeniu uposażenia lub diety powinna określać w granicach, wyznaczonych przez art. 23 ust. 1 regulaminu Sejmu, wysokość

M. Kudej, Zmiany w regulaminie Sejmu uchwalone na początku IV kadencji, „Przegląd Sejmowy" 2002, nr 5, s. 67.

3 Zob. J. Mordwiłko, Wykładnia art. 25 regulaminu Sejmu, stanowiacego o stosowaniu sankcji za wykluczenie posła z posiedzenia Sejmu [w:] Regulamin Sejmu w opiniach Biura Analiz Sejmowych, t. I, red. W. Odrowąż-Sypniewski, Warszawa 2010, s. 163. 
obniżenia oraz okres, przez który będzie ono obowiązywać. Określając wymiar kary, Prezydium Sejmu powinno wziąć pod uwagę wszystkie okoliczności zdarzenia oraz zakres, w jakim czyn posła doprowadził do dezorganizacji prac izby.

Obniżeniu może ulec każde z wymienionych w art. 23 ust. 1 regulaminu Sejmu świadczeń albo oba świadczenia naraz ${ }^{4}$. Konkretny wymiar kary nie musi zakładać takiego samego potrącenia we wszystkich miesiącach objętych okresem wykonania kary (potrącenie $\mathrm{w}$ danym miesiącu nie może jednak przekraczać maksymalnej wysokości).

Uchwała o obniżeniu uposażenia powinna mieć formę pisemną, ponieważ regulamin formułuje wymóg doręczenia tej uchwały posłowi, którego ona dotyczy. Mając na uwadze, że zainteresowanemu przysługuje prawo złożenia wniosku o ponowne rozpatrzenie sprawy przez Prezydium Sejmu (art. 23 ust. 2 regulaminu Sejmu), należy przyjąć, że uchwale powinno towarzyszyć uzasadnienie wyjaśniające motywy rozstrzygnięcia.

2. Sygnalizowana na początku opinii wątpliwość interpretacyjna dotyczy art. 23 ust. 2 regulaminu Sejmu, który przewiduje, że: od uchwaty o obniżeniu uposażenia lub diety parlamentarnej (...) posłowi przystuguje, $w$ terminie 7 dni od dnia doręczenia uchwaty, wniosek o ponowne rozpatrzenie sprawy przez Prezydium Sejmu. Prezydium Sejmu ponownie rozpatruje sprawę po zasięgnięciu opinii Konwentu Seniorów. Z treści tego przepisu wynika, że Prezydium Sejmu może ponownie rozpatrzyć sprawę wyłącznie na wniosek posła, którego dotyczy uchwała wymierzająca karę finansową. Regulamin nie określa formy wniosku, jednak zasadne wydaje się zachowanie formy pisemnej. Termin na wniesienie wniosku należy uznać za spełniony, jeżeli przed upływem 7 dni od dnia doręczenia uchwały do Marszałka Sejmu (reprezentującego w praktyce Prezydium Sejmu) dotrze oświadczenie zainteresowanego (wniosek o ponowne rozpatrzenie sprawy).

Dylemat dotyczący zakresu kompetencji przysługującej Prezydium Sejmu $\mathrm{w}$ ramach rozpatrywania wniosku o ponowne rozpatrzenie sprawy rozstrzygać należy z uwzględnieniem zasad wykładni językowej i systemowej. Przedmiotem wniosku kierowanego do Prezydium Sejmu jest postulat „ponownego rozpatrzenia sprawy" przez Prezydium Sejmu. W tej fazie postępowania rola Prezydium Sejmu nie ogranicza się zatem do oceny prawidłowości pierwotnej uchwały, lecz obejmuje ponową analizę wszystkich okoliczności faktycznych towarzyszących zdarzeniu, dających się ustalić motywów działania sprawcy oraz szkodliwości „czynu”. Ponowne rozpatrzenie sprawy zakłada zatem ocenę zasadności nałożenia sankcji finansowych na posła, który uniemożliwił prace Sejmu lub jego organów, której wynikiem może być utrzymanie w mocy pierwotnej uchwały

4 Zob. wypowiedź Marszałka M. Borowskiego reprezentującego Prezydium Sejmu $\mathrm{w}$ trakcie pierwszego czytania projektu nowelizacji regulaminu Sejmu ustanawiającej omawiany przepis; posiedzenie Komisji Regulaminowej i Spraw Poselskich w dniu 19 kwietnia 2002 r., biuletyn Komisji Regulaminowej i Spraw Poselskich 501/IV kad. 
jak również jej uchylenie (w tym także zmiana wysokości obniżenia świadczeń finansowych lub zmiana okresu, w który obniżenie ma obowiązywać).

Wykładnię językową potwierdzają argumenty natury systemowej. W doktrynie poszczególnych gałęzi prawa procesowego powszechnie przyjęty jest podział środków zaskarżenia na środki odwoławcze - mające charakter dewolutywny i inne środki zaskarżenia - niemające takiego charakteru. Jak wskazał Trybunał Konstytucyjny, wniosek o ponowne rozpatrzenie sprawy, o którym mowa w art. $127 \$ 3$ Kodeksu postępowania administracyjnego (dalej: k.p.a.), jest środkiem prawnym o charakterze niedewolutywnym. Wniesienie tego środka nie powoduje skutku w postaci przesunięcia kompetencji do rozpoznania lub rozstrzygnięcia sprawy na organ wyższego stopnia, lecz powierza ją ponownie temu samemu organowi. Jest natomiast środkiem suspensywnym - do upływu terminu do złożenia wniosku o ponowne rozpoznanie sprawy, a w razie jego wniesienia w terminie do czasu wydania ponownego rozstrzygnięcia, wstrzymane jest wykonanie pierwszego rozstrzygnięcia ${ }^{5}$. Organ rozpatrujący wniosek o ponowne rozpatrzenie sprawy, o którym mowa w art. $127 \$ 3$ k.p.a., jest zobowiązany do powtórnego rozpoznania i rozstrzygnięcia sprawy w całości ${ }^{6}$.

Podobieństwo środka odwoławczego, o którym mowa w art. 23 ust. 2 regulaminu Sejmu, do instytucji z art. $127 \$ 3$ k.p.a. (analogia iuris) uzasadnia ocenę, że regulaminowy wniosek o ponowne rozpatrzenie sprawy jest środkiem o charakterze niedewolutywnym (sprawa ponownie rozpatrywana jest przez ten sam organ - Prezydium Sejmu) oraz suspensywnym (wniesienie odwołania wstrzymuje wykonanie pierwszej uchwały Prezydium Sejmu - art. 23 ust. 3 regulaminu Sej$\mathrm{mu}$ ), a jego rozpatrzenie zakładać powinno powtórne rozpoznanie i rozstrzygnięcie sprawy. W konsekwencji należy uznać, że Prezydium Sejmu, rozpatrując odwołanie, może nie tylko utrzymać tę uchwałę w mocy lub ją uchylić, ale również może zmienić wysokość sankcji finansowej.

Wzgląd na zupełność prezentowanej analizy wymaga postawienia pytania, czy zmiana wysokości sankcji w trybie art. 23 ust. 2 regulaminu Sejmu może polegać wyłącznie na jej uchyleniu lub obniżeniu (zmiana wysokości obniżenia świadczeń lub skrócenie okresu, w którym obniżenie obowiązuje), czy też mogłaby polegać na „podwyższeniu” sankcji wymierzonej w pierwotnej uchwale?

W przepisach regulaminu Sejmu, w szczególności w art. 23, nie został wyrażony zakaz reformationis in peius, czyli zakaz zmiany rozstrzygnięcia na niekorzyść posła odwołującego się od pierwotnej uchwały Prezydium Sejmu. Zakaz reformationis in peius uznawany jest w piśmiennictwie za jedną $\mathrm{z}$ istotnych gwarancji procesowych, służącą ochronie praw jednostki. Jego istotą jest umożliwienie stronie niezadowolonej z uzyskanego rozstrzygnięcia w swojej sprawie wniesienia odwo-

Wyrok Trybunału Konstytucyjnego z 15 grudnia 2008 r., sygn. akt P 57/07.

6 P. Przybysz, Komentarz do art. 127 [w:] Kodeks postępowania administracyjnego. Komentarz, 2017, LEX. 
łania bez obaw, że decyzja organu odwoławczego spowoduje bardziej negatywne skutki niż pierwotna. W przypadku obowiązywania tego zakazu ryzyko skarżącego ogranicza się do pozostawienia w mocy rozstrzygnięcia pierwszej instancji. Zakaz ten nie obowiązuje w sposób bezwzględny. W sytuacji kontradyktoryjności sporu (sprzeczność interesów przeciwników procesowych) możliwe jest, że rozstrzygnięcie odwoławcze pogorszy sytuację jednej z odwołujących się stron ${ }^{7}$. Zakaz reformationis in peius obowiązuje w postępowaniu karnym (art. $434 \$ 1$ zdanie pierwsze Kodeksu postępowania karnego), cywilnym (art. 384 Kodeksu postępowania cywilnego), administracyjnym (art. 139 k.p.a.) i administracyjnosądowym (art. $134 \$ 2$ ustawy - Prawo o postępowaniu przed sądami administracyjnymi).

Lakoniczność procedury określającej tryb rozpatrywania odwołania, o którym mowa w art. 23 ust. 2 regulamin Sejmu, umożliwia stosowanie w niej zasad przewidzianych w innych gałęziach prawa (w szczególności w procedurach prawa represyjnego) w zakresie, w jakim służy to ochronie praw jednostki. Wydaje się zatem, że mimo milczenia regulaminu Sejmu należałoby opowiedzieć się za obowiązywaniem zakazu reformationis in peius w omawianym przypadku (analogia legis z art. $434 \$ 1$ zdanie pierwsze Kodeksu postępowania karnego).

\section{Podsumowanie}

Podsumowaniem opinii jest pogląd, że zakres możliwych rozstrzygnięć Prezydium Sejmu na podstawie art. 23 ust. 2 regulaminu Sejmu obejmuje utrzymanie w mocy pierwotnej uchwały, jej uchylenie oraz zmianę wysokości - orzeczonego w pierwotnej uchwale - obniżenia świadczeń poselskich (w kierunku korzystnym dla odwołującego się posła).

\section{Bibliografia}

Federczyk W., Uwagi na temat obowiązywania zakazu reformationis in peius $w$ postępowaniu administracyjnosądowym, „Kwartalnik Prawa Publicznego” 2004, nr 3.

Kudej M., Zmiany w regulaminie Sejmu uchwalone na początku IV kadencji, „Przegląd Sejmowy" 2002, nr 5.

Mordwiłko J., Wykładnia art. 25 regulaminu Sejmu, stanowiącego o stosowaniu sankcji za wykluczenie posła z posiedzenia Sejmu [w:] Regulamin Sejmu w opiniach Biura Analiz Sejmowych, t. I, red. W. Odrowąż-Sypniewski, Warszawa 2010.

Przybysz P., Komentarz do art. 127 [w:] Kodeks postępowania administracyjnego. Komentarz, 2017, LEX.

W. Federczyk, Uwagi na temat obowiązywania zakazu reformationis in peius w postępowaniu administracyjnosądowym, „Kwartalnik Prawa Publicznego” 2004, nr 3. 